\title{
Accountability as a Deterrent to Self-Enhancement: The Search for Mechanisms
}

\author{
Constantine Sedikides \\ University of Southampton
}

\author{
Deletha P. Hardin \\ University of Tampa
}

Kenneth C. Herbst

Saint Joseph's University

Gregory J. Dardis

United States Military Academy at West Point

\begin{abstract}
Although self-enhancement is linked to psychological benefits, it is also associated with personal and interpersonal liabilities (e.g., excessive risk taking, social exclusion). Hence, structuring social situations that prompt people to keep their self-enhancing beliefs in check can confer personal and interpersonal advantages. The authors examined whether accountability can serve this purpose. Accountability was defined as the expectation to explain, justify, and defend one's self-evaluations (grades on an essay) to another person ("audience"). Experiment 1 showed that accountability curtails self-enhancement. Experiment 2 ruled out audience concreteness and status as explanations for this effect. Experiment 3 demonstrated that accountability-induced self-enhancement reduction is due to identifiability. Experiment 4 documented that identifiability decreases self-enhancement because of evaluation expectancy and an accompanying focus on one's weaknesses.
\end{abstract}

Many, if not most, people regard themselves as slightly superior to others on positive dimensions that are important to them. For example, people rate themselves as above-average spouses and professionals (e.g., teachers, managers). They consider themselves more moral, trustworthy, and physically attractive than others. Perhaps because they overestimate the control they have over their lives, people believe that, compared with others, they are happier, are likely to be healthier and live longer, and are more likely to experience positive life events (e.g., a fulfilling occupation, a good marriage, winning the lottery) but less likely to experience negative life events (e.g., a road accident, chronic disease, unemployment). In fact, people exalt their important attributes even when they evaluate themselves from the perspective of their peers.

Such self-superiority beliefs (i.e., self-enhancement) are well documented (Alicke, 1985; Brown, 1986; Robins \& John, 1997a; Weinstein, 1980). These beliefs are maintained through several processes and strategies, such as idiosyncratic (i.e., favorable to the self) definitions of traits and skills (Dunning, Meyerowitz, \&

Constantine Sedikides, Department of Psychology, University of Southampton, Highfield, Southampton, England; Kenneth C. Herbst, Erivan K. Haub School of Business, Saint Joseph's University; Deletha P. Hardin, Department of Psychology, University of Tampa; Gregory J. Dardis, Department of Psychology, United States Military Academy at West Point.

We thank Aiden Gregg, Michelle Neiss, and Tim Wildschut for their constructive comments on earlier versions of this article. We also thank John d'Adesky, Daniel Chase, Rebecca Kramer, Sean Lemoine, and Lina Zvonar for their assistance with data collection.

Correspondence concerning this article should be addressed to Constantine Sedikides, Department of Psychology, University of Southampton, Highfield Campus, Southampton SO17 1BJ, England, United Kingdom. E-mail: cs2@soton.ac.uk
Holzberg, 1989), better memory for feedback referring to one's strengths rather than weaknesses (Sedikides \& Green, 2000a), taking personal credit for success but disavowing blame for failure (K. W. Campbell \& Sedikides, 1999), affirmation of a self-domain that is unrelated to the self-domain currently under threat (Steele, 1988), psychological distancing from others (Schimel, Pyszczynski, Greenberg, O'Mahen, \& Arndt, 2000), withholding of information that will likely improve others (Pemberton \& Sedikides, 2001), and comparison with less fortunate others (Wills, 1981).

Self-enhancement is associated with short-term psychological benefits, such as a relatively high level of positive affect and self-esteem, as well as persistence in challenging tasks, effective coping with negative health outcomes, and resiliency in the face of adversity (Aspinwall \& Brunhart, 1996; Bonanno, Field, Kovacevic, \& Kaltman, 2002; Robins \& Beer, 2001; Taylor \& Armor, 1996; Taylor \& Brown, 1988). However, self-enhancement is also associated with both short-term and long-term liabilities. With regard to short-term liabilities, self-enhancement is linked to excessive risk taking (Baumeister, Heatherton, \& Tice, 1993; Burger \& Burns, 1988), which may lead to physical injury (Cohen, Dearnley, \& Hansel, 1956), reduced action readiness, and ineffective action plans (Oettingen, 2000). Additionally, excessively selfenhancing individuals are described by their peers in rather disenchanting terms (e.g., as conceited, defensive, uninteresting, and hostile; Colvin, Block, \& Funder, 1995; Paulhus, 1998). This implies that self-enhancers induce a certain level of discomfort, distress, and general unpleasantness in their social circles. Hence, self-enhancers are at risk for experiencing distancing and avoidance treatment, becoming the target of gossip, receiving unfavorable feedback, being distrusted, and facing social exclusion and ostracism (Leary, Bednarski, Hammon, \& Duncan, 1997; Schlenker \& Leary, 1982; Williams \& Zadro, 2001). Long-term liabilities can be equally severe: Persistent self-enhancers may manifest 
future low levels of self-esteem and subjective well-being, and may also become dissatisfied and ultimately disengaged from their professional activities (e.g., academic studies; Robins \& Beer, 2001; Robins \& John, 1997b).

Interestingly, self-enhancement, despite its endurance, appears to be a controllable bias (Alicke, Klotz, Breitenbecher, Yurak, \& Vredenburg, 1995; Krueger, 1998; Kruger, 1999; Sedikides, Campbell, Reeder, \& Elliot, 1998). Given the potentially damaging short-term and long-term personal and interpersonal consequences of having or expressing self-enhancing views, some form of social engineering that may prompt people to keep such views in check (and may also help others to co-exist harmoniously with the self-enhancer) is worth considering. We focus here on one relevant structural or situational constraint: accountability. We define accountability as participants' expectation that they will be called on to explain, justify, and defend their self-evaluations to one or more others (termed "audience"). We examine (a) whether accountability can curtail self-enhancement, and, if so, (b) what mechanisms are responsible for this effect.

\section{Accountability and Self-Enhancement}

The construct of accountability has attracted keen interest in psychology and related disciplines. For example, research has examined the role of accountability in social perception, attitudes, judgment accuracy, organizational behavior, negotiations, and educational curricula. One reason for this remarkable degree of empirical attention is the potential of accountability to serve as a rule for enforcing vital societal norms (Semin \& Manstead, 1983). As Lerner and Tetlock (1999) have asserted, accountability is a variable that bridges the individual and the institutional or social structural level of analysis. Stated alternatively, a social structure or social situation can influence individual behavior through accountability pressures (Schlenker, Weigold, \& Doherty, 1991). It is mostly in that spirit that we wish to explore the role of accountability in self-evaluation.

We modeled our research paradigm after situations that involve self-evaluation on a personally important domain, such as creativity, intelligence, or, more generally, academic ability. To be more exact, we were interested in situations in which participants generate creative input, are asked to judge its merit, and, before they do so, are informed that they will (or will not) be accountable to an audience for their judgment. We wanted to find out if selfevaluations are influenced by accountability.

Let us describe the prototypic experimental paradigm in more detail. We asked undergraduate student participants to write a short opinion essay and then prepare to grade it on the basis of several predefined criteria. However, before actually grading their essay, half of the participants learned that they would be accountable for their assigned grades to an audience, whereas the remaining half believed that they would be unaccountable. Would the grades that participants assigned to their own essay be a function of accountability?

To address this question, we will need to proceed with a further analysis of our experimental paradigm. To begin with, the views of the audience were unknown to participants. That is, participants did not know whether the audience liked or disliked their essay. Second, personal relevance was high. The essay evaluation pertained directly to an attribute (i.e., writing ability) that participants consid- ered important to have (as we verified empirically). Also, we reasoned that participants will likely have feelings of ownership (Beggan, 1992), volitional control (Ryan \& Connell, 1989), and responsibility (Schlenker, 1997) for output that they generate themselves, and, thus, will assign increased importance to it. Third, the audience had no outcome control (i.e., power) over participants.

The effects of accountability on judgmental bias have been equivocal: Sometimes accountability has no effect on the direction of judgment, other times accountability increases judgmental bias, and still other times accountability decreases bias (Lerner \& Tetlock, 1999; Tetlock, 1992). Obviously, the effects of accountability are susceptible to structural elements of the relevant situation, to the topic about which accounts are given, and to individual differences of account givers. Given the features of our experimental paradigm, it is unclear whether accountability will have a null, augmenting, or attenuating effect on the positivity of self-evaluations.

It is well-established that participants shift their views strategically to fit those of the audience to whom they are accountable, but only when participants know (Sedikides, 1990; Tetlock, Skitka, \& Boettger, 1989) or can guess (Weigold \& Schlenker, 1991) the audience's views. Furthermore, participants tailor their attitudes to those of the audience, but mostly when the issue at stake is not personally relevant to them (Eagly \& Chaiken, 1993; Petty \& Cacioppo, 1990). Moreover, participants modify their views in the direction of the audience's views, but mainly when the audience has outcome control over them (Stenning, 1995). In light of these considerations, the minimal accountability pressures incorporated in the current research paradigm are not expected to influence the positivity of self-evaluations. This analysis anticipates a null effect.

Nevertheless, other lines of theory and research bear out the prediction that accountability will boost self-enhancement. According to the false consensus effect (Krueger \& Clement, 1994), participants overestimate the similarity of their own views and those of an audience, especially when the self is threatened (Sherman, Presson, \& Chassin, 1984). Given that participants generally think positively of themselves (Brown \& Dutton, 1995; Sedikides, 1993), they will assume that the audience also holds a favorable view of them (Felson, 1993). Indeed, participants may be particularly motivated to assume consensus in regards to personally important attributes (e.g., writing ability), as the absence of such consensus is threatening. Hence, accountable participants will feel at ease in recording an overblown evaluation of their essay. Research on self-presentation is also relevant to this prediction. People are generally motivated to present themselves favorably to others (Baumeister, 1982; Schlenker, 1980). When feeling threatened, however, people can compensate by putting on a glowing public persona (Greenberg \& Pyszczynski, 1985). Interestingly, Tetlock (1999) drew a parallel between accountable individuals and politicians who strive to protect their identity in the presence of key constituencies. Both will engage in compensatory selfenhancement. In a related vein, Gelfand and Realo (1999) showed that accountability induces culturally normative behavior. Assuming that individualism is the normative behavior in the West, we would expect for accountability to gear participants into a favorable self-presentation mode, which will manifest itself through inflated essay grades. 
Still, other lines of theoretical and empirical inquiry lead to the prediction that accountability will curtail self-enhancement. When the audience's views are unknown, much depends on whether participants are motivated to think carefully of the situation in which they find themselves. In the current experimental paradigm, the audience was a complete stranger to participants. Hence, there is reason to suspect that participants will expect for the audience to be objective. This expectation will constrain the favorability of participants' self-presentation (Baumeister \& Jones, 1978; Schlenker \& Leary, 1982), will motivate them to examine their work in a like-minded (i.e., impartial) manner (Chen, Shecter, \& Chaiken, 1996; Tetlock, 1983), perhaps in an effort to secure audience approval (Baumeister \& Leary, 1995; Insko, Drenan, Solomon, Smith, \& Wade, 1983), or will lead them to tone down their essay appraisal to avoid giving off the impression of a self-centered braggart (Tetlock \& Lerner, 1999; Tice, Butler, Muraven, \& Stillwell, 1995). As a result, accountable participants might engage in what Tetlock (1983) labeled "preemptive self-criticism": They would appraise their work critically, anticipate counterarguments, and incorporate the most plausible counterarguments into their essay evaluation. The result will be lower essay grades.

We addressed relative self-enhancement reduction. That is, we contrasted the self-evaluation of accountable participants with that of unaccountable participants. Do the former self-enhance less than the latter? Relative self-enhancement can testify to the controllability of the self-enhancement bias, as it addresses the question "Can and do accountable participants control selfenhancement?" Furthermore, relative self-enhancement is a signature of participants' strivings to satisfy simultaneously (a) their desire to present the self favorably (Baumeister, 1982; Schlenker, 1980), (b) the impositions of a demanding social situation (i.e., accountability to an audience; Sedikides, 1990; Tetlock et al., 1989), and (c) their own private needs for maintaining a favorable opinion of the self (Greenwald \& Breckler, 1985; Schlenker \& Weigold, 1992). Relative self-enhancement, then, reflects interpersonal and intrapersonal strivings, although it cannot distinguish between them.

\section{Experiment 1: Does Accountability Curtail Self-Enhancement?}

In Experiment 1, we explored the influence of accountability on self-enhancement. We were open to all three theoretical possibilities that we laid out in the introduction. Accountability may have no effect on self-enhancement, may boost self-enhancement, or may curtail self-enhancement. Participants wrote a one-page opinion essay, learned that they would be either accountable or unaccountable to an audience for the grades they would assign to their own essay, graded their essay, and responded to dependent measures and manipulation checks.

\section{Method}

\section{Participants and Design}

We tested 77 participants, using a one-way design with two levels: accountability $(n=41)$ and unaccountability $(n=36)$.

In this and all subsequent experiments, (a) participants were University of North Carolina at Chapel Hill undergraduate students (approximately $65 \%$ women) fulfilling an introductory psychology course option, (b) the gender of the person to whom participants were ostensibly accountable (i.e., Chris Becker) was varied to match each participant's gender, (c) participant gender did not yield any statistically significant effects, (d) all statistically significant effects (of theoretical interest or not) are reported as are theoretically relevant but null effects, (e) careful postexperimental questioning revealed that no participant was aware of the actual purpose of the research, and (f) participants were thoroughly debriefed and thanked at the end of each experimental session.

\section{Procedure}

Participants reported to the laboratory in groups of 5-7 and were assigned randomly to one of the two experimental conditions. The experimenter escorted each participant to a private room and stated that the study was part of a larger, interuniversity research program that investigated alternative grading systems. Each participant was asked to write a one-page essay in response to the question "Should the United States pursue exploration of the planet Mars?" Participants were informed that "there is no right or wrong answer-this is an opinion question." On completion of the essay, participants in the accountability condition received the following instructions:

Next, we will ask you to grade your essay on five dimensions. You will then be given the opportunity to explain, justify, and defend the grades you gave yourself to a 5th-year graduate student, located in an adjoining office, during a 10-minute conversation. The graduate student, Chris Becker, has a Master's degree in Logic and English Composition and is currently completing a doctorate degree in these two fields. Chris Becker is widely published, and has won numerous writing and teaching awards. You will be asked to fully explain, justify, and defend the grades you assigned yourself on each and every dimension.

To reinforce perceptions of accountability, participants were also instructed to "write ... your first name on each page of your booklet ... so that we can keep your responses together."

Participants in the unaccountability condition received the following instructions:

Next, we will ask you to grade your essay on five dimensions. You should understand that all of your grades will be completely confidential and not traceable to you personally. In fact, your grades will not even be available to researchers at this university. Your grades (along with your essay) will be mailed to researchers at another university who collaborate on this project and specialize in alternative grading systems.

To reinforce perceptions of unaccountability, participants were instructed not to write their names on the booklet but rather "use a 5-digit number of your own choosing on top of each page ... so that we can keep your responses together."

In an effort to maintain the plausibility of the pretext, we instructed all participants to "assign yourself letter grades, whereas other participants in this study will use an experimental grading system." It should be noted that we used this instruction in all reported experiments. Participants then graded their essays using letter grades that ranged from $A$ to $F(A, A-, B$, $B-, C, C-, D, D-, F)$. Next, participants in the accountability condition were asked if they believed that they would have to explain, justify, and defend their responses to an accomplished writer. Participants in the unaccountability condition were asked if they believed that their responses were anonymous and confidential. Participants responded by circling either Yes or No. 


\section{Results and Discussion}

\section{Manipulation Checks}

The manipulation was successful. All participants in the accountability condition believed that they would have to explain, justify, and defend their responses, whereas all participants in the unaccountability condition believed that their responses were anonymous and confidential.

\section{Essay Grading}

Each participant graded her or his essay on five dimensions: clarity of thinking, writing style, smoothness of sentence and paragraph transition, logic of arguments, and persuasiveness of argument. We converted the letter-grade scale to a $1(F)$ to $9(A)$ scale for data analytic purposes. Given that grades on the five dimensions were internally consistent $(\alpha=.86)$, we computed a composite index and entered it into an analysis of variance (ANOVA). Accountable participants $(M=6.31)$ gave their essays lower grades than unaccountable participants $(M=6.82), F(1$, $75)=3.89, p<.05$. Accountability curtailed self-enhancement.

\section{Experiment 2: The Role of Audience Concreteness and Status}

Experiment 1 demonstrated that accountability is effective in reducing self-enhancement. Experiment 2 set to test an explanation (i.e., audience concreteness) for this effect, while also seeking to unconfound the potential influence of another variable (i.e., audience status) from the influence of accountability.

The self-enhancement reduction observed in Experiment 1 may be due to accountable participants believing that their essays and grades would be seen by an eponymous other when unaccountable participants were under the impression that their essays and grades would be seen by a generalized other. Indeed, accountable participants were instructed that the audience was a concrete person (i.e., Chris Becker), whereas unaccountable participants were told that their essays and grades would be mailed to researchers at another university. Past research has shown that participants control effectively the self-enhancement bias (as operationalized by the betterthan-average effect) when they compare themselves with a concrete rather than a generalized other (Alicke et al., 1995). In Experiment 2, both accountable and unaccountable participants learned that their essays and grades would become available to a specific person, Chris Becker. This experiment equalized source concreteness.

The audience to whom participants in Experiment 1 were accountable was a high-status source, as it possessed socially approved characteristics such as knowledge, credibility, prestige, and legitimacy (Benoit-Smullyan, 1944; McGuire, 1985; Tyler, 1997). High-status sources command attention, instigate careful processing of information, and, most importantly, evoke yielding to persuasive argumentation, conformity, and compliance (Cialdini \& Trost, 1998; Petty \& Wegener, 1998; Sedikides, 1997). Thus, it is possible that the self-enhancement reduction observed in Experiment 1 is due to status rather than accountability: Participants may have lowered their essay evaluations not because of the pressure to account for their essay grades, but rather because of the presumed presence of an anticipated interaction with a high-status audience.
Participants, for example, may have been motivated to yield to the audience's expertise and legitimacy, comply ingratiatingly with the audience, or avoid giving off the impression of arrogance. To disentangle the effect of accountability from that of status, we manipulated orthogonally these two variables. Of particular interest was the statistical interaction effect. The presence of an interaction would establish status as an explanation for the accountability-induced attenuation in self-enhancement, whereas the absence of an interaction would cast serious doubt to such an explanation.

In addition, Experiment 2 sought to verify that participants regarded the skill of good writing as an important attribute to have. Finally, in this experiment the accountability manipulation check was numerical rather than nominal. This modification acknowledges that participants may regard confidentiality as varying on a continuum rather than as absolute.

\section{Method}

\section{Participants and Design}

We tested 82 participants. The design was a 2 (accountability vs. unaccountability) $\times 2$ (high audience status vs. low audience status) between-subjects factorial. Cell sizes ranged from 20 to 21 .

\section{Materials}

The cover story and essay assignment were the same as in Experiment 1. The accountability manipulation was similar to that of Experiment 1 . Specifically, accountable participants were instructed that they would grade their essay and then explain, justify, and defend their grades during a short conversation with Chris Becker. However, unaccountable participants were instructed that their essay and grades would be anonymous and confidential, although they would become available (along with other participants' essays and grades) to Chris Becker.

Additionally, participants in the high-audience-status condition learned that Chris Becker was a star doctoral candidate in Logic and English Composition (as in Experiment 1). However, participants in the lowaudience-status condition learned that Chris Becker was a work-study student who attended the local high school. The student was described as a "high school senior who hopes to attend college next year. Chris attends the local high school and is active in sports and several clubs. Chris participates in a university pilot program that identifies students who are interested in going to college and then provides them with exposure to higher education and career opportunities before they leave high school."

Next, participants completed the main dependent measure: They graded their essays along the same five dimensions as in Experiment 1, but using 11 (instead of 9) letter grades $(A, A-, B+, B, B-, C+, C, C-, D+$, $D, F)$. Subsequently, participants rated the personal importance of having good writing skills on the following statement: "It is important to me to be a good essay writer" $(1=$ not at all true, $7=$ extremely true $)$. Participants also completed an accountability manipulation check by responding to the statement, "My grading of the essay will be __ " $(1=$ completely confidential, $7=$ attributable to me personally). Finally, participants completed a status-manipulation check by responding to the question, "How would you assess Chris Becker's status as an essay reviewer?" $(1=$ very low, 7 = very high).

\section{Results}

\section{Manipulation Checks}

The accountability manipulation was effective: Compared with their unaccountable counterparts $(M=1.31)$, accountable partic- 
ipants thought that their essay grades would be attributable to them personally $(M=6.10), F(1,78)=328.28, p<.01$. The status manipulation was also effective: Compared with participants in the low-audience-status condition $(M=2.83)$, those in the highaudience-status condition $(M=6.51)$ perceived Chris Becker as having higher essay-reviewer status, $F(1,78)=444.46, p<.01$.

\section{Essay Grading}

We computed a composite grade index $(\alpha=.87)$ and entered it in a 2 (accountability) $\times 2$ (audience status) ANOVA. The two main effects were significant. Accountable participants $(M=7.71)$ allocated lower essay grades than unaccountable participants $(M=9.43), F(1,78)=93.54, p<.01$. This finding replicates Experiment 1, in showing that accountability curtails selfenhancement. The finding also rules out audience concreteness as an explanation for this effect.

Participants in the high-audience-status condition $(M=8.25)$ assigned their essay lower grades than participants in the lowaudience-status condition $(M=8.93), F(1,78)=14.82, p<.01$. Audience status curtailed self-enhancement. Of importance, however, the interaction was not significant, $F(1,78)=1.28, p<.26$. Audience status did not qualify the accountability-induced curtailment of self-enhancement.

\section{Attribute Importance}

Participants considered being a good essay writer a personally important attribute $(M=5.60)$, as demonstrated by a $t$ test against the scale midpoint $(4), t(81)=12.00, p<.01$. Accountable and unaccountable participants did not differ in their assessments of attribute importance, $F(1,78)=1.62, p<.21$.

\section{Discussion}

Experiment 2 disqualified audience concreteness as an explanation for why accountable participants curtail self-enhancement: These participants self-enhanced less than their unaccountable counterparts even when audience concreteness was held constant.

Audience status diminished the degree of self-enhancement. This is not surprising. The high-status audience was likely perceived as higher on expertise and legitimacy, and perceived legitimacy leads to substantial accountability effects (e.g., more accurate and complex evaluations; Cvetkovich, 1978; Gordon \& Stuecher, 1992). Interestingly, however, audience status did not appear to be a plausible reason why accountable participants reduce self-enhancement: These participants curtailed the positivity of their self-evaluations regardless of whether they expected to interact with a high- or low-status audience.

\section{Experiment 3: The Role of Identifiability}

Experiment 3 continued the search for an explanation of the accountability-induced reduction in self-enhancement. We assumed that accountability is a multicomponent construct (Lerner \& Tetlock, 1999, p. 255) and proceeded with an attempt to pinpoint the component most responsible for the self-enhancement curtailment effect. (For the general logic behind this approach, see Cronbach, 1955; Kenny \& Albright, 1987.) Specifically, we explored identifiability as a plausible reason for this effect. This variable refers to whether participants believe that their selfevaluations can be linked to them personally. In our previous two experiments, we confounded accountability with identifiability: Accountable participants were identifiable, but unaccountable participants were not.

Individuals are particularly likely to be amenable to normative social influence (Deutsch \& Gerard, 1955) under conditions of identifiability. It is not surprising, then, that identifiability reduces self-interested behavior. Compared with their unidentifiable counterparts, identifiable group members exert more effort (Williams, Harkins, \& Latane, 1981), make more gracious attributions for the value of others' contribution to task success (Weary-Bradley, 1978), are less greedy (Diener, Fraser, Beaman, \& Kelem, 1976), behave less discriminatorily (Dobbs \& Crano, 2001) and more cooperatively (Schopler et al., 1995) toward outgroup members, diffuse differences between the ingroup and the outgroup (Reicher \& Levine, 1994), contribute more substantially to public goods (De Cremer, Snyder, \& Dewitte, 2001), and are less aggressive (Singer, Brush, \& Lublin, 1965). Following this literature, it is likely that identifiability deters another self-interested behavior: inflated appraisals of one's own work.

We conducted an experiment to examine whether identifiability qualifies as a mechanism through which accountability (to a highstatus audience) reduces self-enhancement. A third of the participants were unaccountable. Another third were accountable and identifiable. (This condition simulates such real-life situations as a student defending her doctoral dissertation before a faculty committee.) These two conditions were identical to those of Experiments 1 and 2. An additional condition involved participants who were accountable but unidentifiable. (This condition simulates such real-life situations as a religious confession.)

We hypothesized that, if identifiability is a reason for selfenhancement reduction, then this effect will be more pronounced in the accountable and identifiable condition than the accountable and unidentifiable condition. If, however, identifiability is not a reason for this effect, then participants in these two conditions will self-enhance at a similar (i.e., not significantly different) level. Finally, we would expect for participants in the accountability and identifiability conditions to self-enhance less than unaccountable participants, thus replicating the previous experiments.

Additionally, Experiment 3 explored participants' affective states. Do accountable and identifiable participants feel worse (i.e., more nervous, tense, and anxious) than accountable and unidentifiable or unaccountable participants? Finally, this experiment clarified the manipulation checks (by using different questions for accountability and identifiability) and improved the assessment of attribute importance.

\section{Method}

\section{Participants and Design}

We tested 150 participants using a balanced, one-way, three-level design. In one level, participants were both accountable and identifiable (accountability/identifiability condition). In another level, participants were accountable but unidentifiable (accountability/unidentifiability condition). In the third level, participants were unaccountable (unaccountability condition). 


\section{Procedure}

The cover story was identical to that of the previous experiments. It should be noted that we completed Experiments 1 and 2 before the successful landing of Pathfinder on planet Mars in July 1997. Thus, in Experiment 3 (and in Experiment 4), we changed the essay question to another timely topic: "Should the United States pursue exploration of the planet Saturn?"

After writing the essays, all participants learned that soon they would be asked to grade them. Additionally, accountable/identifiable participants were informed that they would need to explain, justify, and defend their grades eponymously to Chris Becker. Accountable/unidentifiable participants were instructed that they would need to explain, justify, and defend their grades in writing. Their accounts, however, would be anonymous. Another person (Chris Becker) would later read and scrutinize their accounts, essays, and grades, but the participants would always remain unidentifiable. Unaccountable participants received the same instructions as those in the unaccountability condition of Experiment 1.

Next, all participants completed the dependent measures. They graded their essay on the same five dimensions and 11-point scales as in Experiment 2. They also indicated the importance that they assigned to good writing on three statements ("It is important to me to be a good essay writer," "Being a good essay writer is important to my identity," "It means a lot to me to be a good essay writer"), using a 7-point scale ( $1=$ not at all true, $7=$ extremely true). Then, participants rated the degree to which they felt nervous ("I am feeling nervous right now"), tense ("I am feeling tense right now"), and anxious ("I am feeling anxious right now") on 7 -point scales $(1=$ not at all true, $7=$ extremely true $)$.

Finally, participants completed several manipulation checks. First, they indicated the extent to which they thought that their essay grading was confidential $(1=$ completely confidential, $7=$ can be traced to me personally). This was the identifiability check. Second, they indicated their perceptions of accountability by checking one of the two following statements: "I will need to explain, justify, and defend my essay grades"; "I do not need to explain, justify, or defend my essay grades." Participants were assigned a dichotomous score $(1,2)$ based on their responses. This was the accountability check. In addition, participants responded to the statement, "I expect to be evaluated on my grades and essay" $(1=y e s, 2=n o)$. This was the evaluation expectancy check.

\section{Results}

Given the exploratory nature of the experiment, we carried out analytical comparisons using Tukey's honestly significant difference (in the case of ANOVAs) and single degree of freedom tests (in the case of chi-square analyses). It should be noted that a few participants (range: 10-13, evenly distributed across conditions) failed to complete the identifiability manipulation check, the evaluation expectancy manipulation check, the attribute importance measure, and the affective-states measure.

\section{Manipulation Checks}

Identifiability. The main effect was significant, $F(2$, $134)=16.40, p<.01$. Accountable/identifiable participants $(M=4.21)$ indicated that their essay grades could be traced to them personally to a greater degree than either accountable/unidentifiable $(M=2.71)$ or unaccountable $(M=1.91)$ participants, both $p$ s $<.001$. Accountable/unidentifiable and unaccountable participants did not differ significantly in their perceptions of identifiability, $p<.11$. This manipulation check was successful in documenting that accountable/identifiable participants showed the most pronounced subjective perceptions of identifiability.
Accountability. The main effect was significant, $\chi^{2}(2)=$ 26.21, $p<.01$ (see Table 1). A higher number of participants perceived themselves as accountable (i.e., needing to explain, justify, and defend their essay grades) rather than unaccountable in the accountability/identifiability condition compared with either the accountability/unidentifiability condition, $\chi^{2}(1)=11.82, p<$ .01 , or the unaccountability condition, $\chi^{2}(1)=4.02, p<.05$. Additionally, more participants perceived themselves as accountable rather than unaccountable in the accountability/unidentifiability condition compared with the unaccountability condition, $\chi^{2}(1)=26.30, p<.01$. In summary, the manipulation check showed that subjective perceptions of accountability were the highest when participants felt accountable and identifiable and were the lowest when participants felt unaccountable.

Why would participants in the accountability/identifiability condition perceive higher accountability than participants in the accountability/unidentifiability condition? One reason may be found in lay perceptions of accountability. Perhaps the constructs accountability and identifiability are inextricably linked in common parlance, as manifested by such terms as "being held accountable," with the word held implying identifiability. Stated otherwise, our experimental attempt to unconfound the construct accountability from the construct identifiability may not have corresponded fully to lay conceptions of accountability.

Evaluation expectancy. The main effect was significant, $\chi^{2}(2)=13.51, p<.01$ (see Table 2). A higher number of participants expected to be evaluated (rather than not) in the accountability/identifiability condition compared with either the accountability/unidentifiability condition, $\chi^{2}(1)=3.71, p<.05$, or the unaccountability condition, $\chi^{2}(1)=13.42, p<.01$. Additionally, more participants expected to be evaluated (rather than not) in the accountability/unidentifiability condition compared with the unaccountability condition, $\chi^{2}(1)=3.66, p<.06$. In summary, this manipulation check was successful in demonstrating that accountable/identifiable participants held the strongest evaluation expectancies, whereas unaccountable participants held the weakest evaluation expectancies.

\section{Essay Grading}

We computed a composite grade index $(\alpha=.88)$ and entered it into an ANOVA. The main effect was significant, $F(2$, $147)=5.32, p<.01$. One purpose of Experiment 3 was to test the replicability of the previous experiments. Thus, we compared the essay evaluation of accountable/identifiable participants with that of unaccountable participants. The former group $(M=7.21)$ allocated lower essay grades than the latter $(M=8.27), p<.01$.

Table 1

Accountability Manipulation Check in Experiment 3

\begin{tabular}{lcc}
\hline \multicolumn{1}{c}{ Condition } & $\begin{array}{c}\text { Perceived } \\
\text { accountability } \\
(n)\end{array}$ & $\begin{array}{c}\text { Perceived } \\
\text { unaccountability } \\
(n)\end{array}$ \\
\hline Accountability/identifiability & 40 & 5 \\
Accountability/unidentifiability & 28 & 21 \\
Unaccountability & 16 & 28 \\
\hline
\end{tabular}


Table 2

Evaluation Expectancy Manipulation Check in Experiment 3

\begin{tabular}{lcc}
\hline \multicolumn{1}{c}{ Condition } & $\begin{array}{c}\text { Perceived } \\
\text { evaluation } \\
(n)\end{array}$ & $\begin{array}{c}\text { Perceived } \\
\text { nonevaluation } \\
(n)\end{array}$ \\
\hline Accountability/identifiability & 38 & 7 \\
Accountability/unidentifiability & 33 & 16 \\
Unaccountability & 21 & 23 \\
\hline
\end{tabular}

Accountable participants manifested a decreased level of selfenhancement, a finding consistent with Experiments 1 and 2.

A more compelling objective of Experiment 3 was to find out if identifiability is a reason why accountable participants curtail their self-enhancement bias. We compared the essay grading of accountable/identifiable participants with that of accountable/unidentifiable participants. The former group assigned their essays lower grades than the latter $(M=7.94), p<.04$. Identifiability indeed emerged as an explanation for self-enhancement curtailment. This claim was bolstered by another comparison: Accountable/unidentifiable participants did not give their essay significantly different grades than unaccountable participants, $p<.58$. That is, unidentifiable participants manifested self-interested behavior (i.e., self-enhancement), regardless of accountability pressures.

As we reported previously, the accountability manipulation check revealed that participants in the accountability/unidentifiability condition perceived themselves more accountable than those in the unaccountability condition. The essay grading results did not track these manipulation check results. We wondered whether self-enhancement would be observed even after covarying out the accountability manipulation check. Indeed, this was the case, $F(1,145)=6.57, p<.01$. The covariate effect was not significant, $F(1,145)=2.07, p<.15$.

\section{Attribute Importance}

We computed an attribute importance composite $(\alpha=.85)$ and entered it into an ANOVA. In replication of Experiment 2, participants considered being a good essay writer a personally important attribute $(M=4.44)$, as indicated by a $t$ test against the scale midpoint (4), $t(137)=3.44, p<.01$. Participants did not differ significantly among conditions in the importance that they ascribed to good essay writing, $F(2,135)=1.77, p<.17$.

\section{Affective States}

We also explored participants' affective states. We computed a composite affective-states score $(\alpha=.89)$ and entered it into an ANOVA. The main effect was significant, $F(2,136)=3.06, p<$ .05 . Accountable/identifiable participants $(M=2.66)$ felt worse (i.e., more nervous, tense, and anxious) than accountable/unidentifiable participants $(M=1.91), p<.05$. Surprisingly, accountable/identifiable participants did not feel (significantly) worse than unaccountable participants $(M=2.49), p<.87$. Finally, accountable/unidentifiable and unaccountable participants did not differ significantly in the way they felt, $p<.17$.

\section{Discussion}

Experiment 3 succeeded in its search for an explanation for why accountability deters self-enhancement. This explanation is identifiability. Accountable participants lower their self-enhancement because they are identifiable. Indeed, when unidentifiable, accountable participants revert to their self-interested behavior (Reicher \& Levine, 1994; Schopler et al., 1995): They inflate the appraisals of their work to a level that is practically indistinguishable from that of unaccountable participants.

Why does identifiability curtail self-enhancement in accountable participants? A reason may be evaluation expectancy. Indeed, the evaluation expectancy manipulation check pointed to this direction. Accountable and identifiable participants expressed stronger evaluation expectancies than their unaccountable counterparts. Furthermore, accountable and identifiable participants were inclined to believe that they more likely to be subject to evaluation than their accountable and unidentifiable counterparts, and they also felt worse than them.

\section{Experiment 4: The Role of Evaluation Expectancy}

In Experiment 4, we examined the possibility that accountable and identifiable participants curtailed their self-enhancement because they expected to be evaluated by a (high-status) audience. Indeed, literature attests to the notion that evaluation expectancy can inhibit self-interested behavior (Geen, 1991; Harkins \& Jackson, 1985; Sanna, 1992). We were concerned with one particular sequence of processes through which this effect is achieved. Evaluation expectancy is known to lead to evaluation apprehension (Cottrell, 1968; Henchy \& Glass, 1968), which in turn induces a state of self-focused attention. Self-focus increases awareness of discrepancies from internal (performance, social, or moral) standards (Duval \& Wicklund, 1972; Sedikides, 1992a; Wicklund, 1975), thus rendering personal weaknesses accessible in memory (Sedikides \& Skowronski, 1991a, 1991b). These weaknesses will figure in self-judgments. The result will be deflated self-appraisals of one's standing in the evaluative domain under consideration.

In Experiment 4, we tested directly the role of evaluation expectancy in self-enhancement curtailment among accountable and identifiable participants. We manipulated orthogonally accountability and evaluation expectancy, and assessed level of selfenhancement (i.e., essay grades) as well as degree of focus on weaknesses as a writer. A real-life example of an accountability/ high-evaluation-expectancy situation is (again) the case of a student defending her doctoral dissertation. However, a real-life example of an accountability/low-evaluation-expectancy situation is the case of a student practicing the dissertation oral defense before a group of peers. The contribution of evaluation expectancy to reduced self-enhancement would be manifested through a significant interaction effect, in which accountable and high-evaluationexpectancy participants gave their essays disproportionately low grades.

\section{Method}

\section{Participants and Design}

We tested 115 participants. The design involved a 2 (accountability, unaccountability) $\times 2$ (high evaluation expectancy, low evaluation expectancy) between-subjects factorial. Cell sizes ranged between 24 and 33 . 


\section{Procedure}

The accountability condition was identical to the accountability/identifiability condition of Experiment 3, whereas the unaccountability condition was identical to the unaccountability condition of Experiment 3. We will proceed with a description of the evaluation expectancy manipulation.

High-evaluation-expectancy participants were instructed that the audience (i.e., Chris Becker) had a hard-earned reputation for being very evaluative and judgmental, and that Chris would be evaluating "every single sentence of your essay, every single thought that you expressed, every single twist and turn." (Accountable participants also learned that Chris Becker would have the same overly evaluative attitude toward their explanations and justifications for their grade assignment.) In addition, participants were told that Chris Becker would carefully record his or her impression of their essay in a personal notebook. However, lowevaluation-expectancy participants were instructed that Chris had a welldeserved reputation for being very nonevaluative and nonjudgmental, and that Chris would receive their essays and grades in a completely nonevaluative and nonjudgmental manner. (Accountable participants also learned that Chris Becker would have the same relaxed and nonevaluative attitude toward their explanations and justifications for their grade assignment.) Chris would not record his or her impressions, and, in fact, would refrain from forming any impression of their essay.

Participants proceeded with the completion of several manipulation checks. First, they responded to the confidentiality check: They indicated the extent to which they thought that their essay grading was confidential $(1=$ completely confidential, $7=$ can be traced to me personally). Second, they completed the accountability check: They indicated whether they believed that they were accountable by checking one of the following statements: "I will need to explain, justify, and defend my essay" and "I do not need to explain, justify, or defend my essay." Third, participants completed the first evaluation expectancy check: They responded to the statement, "I expect to be evaluated on my grades and essay" ( 1 = not true, 7 = extremely true). Subsequently, participants responded to the main dependent measure: They graded their essay on the same five dimensions and 11-point scales as in Experiments 2 and 3.

Following the dependent measure, participants completed the second, more critical, check of the effectiveness of the evaluation expectancy manipulation. This was the weakness focus assessment. Specifically, participants reported the extent to which they were currently focused on their weaknesses in their writing skills ("I am thinking about my weaknesses as a writer right now," "I am thinking about my bad qualities as a writer right now," "I am thinking about the deficiencies in my writing right now") on a scale that ranged from 1 (not at all true) to 7 (extremely true). Finally, participants indicated the importance they ascribed to being a good writer and recorded their affective states using scales identical to those of Experiment 3.

\section{Results}

The degrees of freedom will vary slightly, because a few participants (range: 2-3) did not complete the confidentiality manipulation check, the evaluation expectancy manipulation check, and the essay grading measure.

\section{Manipulation Checks}

Confidentiality. The confidentiality manipulation check was effective. Accountable participants $(M=3.69)$ indicated that their essay grades could be traced to them personally to a greater degree than unaccountable participants $(M=2.52), F(1,109)=11.35$, $p<.01$.

Accountability. All participants in the accountability condition stated that they needed to explain, justify, and defend their essay grades, whereas all participants in the unaccountability condition agreed with the statement that they would not need to explain, justify, and defend their essays.

Evaluation expectancy. As stated previously, we assessed the effectiveness of the evaluation expectancy manipulation through two checks. The first manipulation check, collected prior to the main dependent measure, referred to whether participants expected to be evaluated on their grades and essay. The evaluation expectancy main effect was not significant, $F(1,108)=1.07, p<.30$, although descriptively the means were in the anticipated direction: High-evaluation-expectancy participants $(M=4.39)$ expected to be evaluated to a minimally greater extent than low-evaluationexpectancy participants $(M=4.03)$. Arguably, this is not surprising, as participants in both conditions expected for the audience (i.e., Chris Becker) to examine their essays and grades. Of greater interest, accountable participants $(M=4.64)$ tended to have stronger evaluation expectancies than unaccountable participants $(M=3.93), F(1,108)=3.68, p<.06$. Of importance, the absence of a significant interaction, $F(1,108)=0.11, p<.74$, suggests that participants in the two accountability conditions held equally strong evaluation expectancies.

The second, more critical, manipulation check involved the weakness focus assessment, and was collected following the main dependent measure. Participants indicated the extent to which they focused on their writing weaknesses on three items (i.e., weaknesses, bad qualities, deficiencies). We computed a composite score $(\alpha=.96)$ and entered it into an ANOVA. Critically, highevaluation-expectancy participants $(M=4.47)$ focused more on their weaknesses than low-evaluation-expectancy participants $(M=3.65), F(1,111)=5.06, p<.03$. The anticipation of evaluation by a highly judgmental person led participants to focus on their inadequacies. Interestingly, accountable participants $(M=4.43)$ tended to focus on their weaknesses to a greater degree than unaccountable participants $(M=3.82), F(1,111)=3.27, p<$ .07 . The Accountability $\times$ Evaluation Expectancy interaction was not significant, $F(1,111)=0.93, p<.34$.

\section{Essay Grading}

We computed a composite grade index $(\alpha=.88)$ and entered it into an ANOVA. The accountability main effect was significant. Accountable participants $(M=7.09)$ allocated significantly lower essay grades than unaccountable participants $(M=7.79), F(1$, $109)=4.54, p<.04$. This finding replicates past experiments in showing that accountability reduces self-enhancement. The evaluation expectancy main effect was not significant, $F(1$, 109) $=1.47, p<.23$.

Of importance, however, the Accountability $\times$ Evaluation Expectancy interaction was significant, $F(1,109)=8.62, p<.01$. Accountable and high-evaluation-expectancy participants $(M=$ 6.37) gave their essays significantly lower grades than accountable and low-evaluation-expectancy participants $(M=7.78), F(1$, $109)=7.37, p<.02$. Moreover, accountable and high-evaluationexpectancy participants $(M=6.37)$ assigned their essays significantly lower grades than unaccountable and high-evaluationexpectancy participants $(M=8.08), F(1,109)=12.68, p<.01$. Clearly, evaluation expectancy qualifies as a reason for selfenhancement curtailment. 


\section{Attribute Importance}

We computed and entered the attribute importance composite ( $\alpha$ $=.84$ ) into an ANOVA. Replicating Experiments 2 and 3, participants deemed being a good essay writer a personally important attribute $(M=4.41)$, as revealed by a $t$ test against the scale midpoint (4), $t(114)=3.10, p<.01$. Participants did not vary in their importance ratings as a function of accountability, $F(1$, $111)=1.04, p<.31$, evaluation expectancy, $F(1,111)=0.55$, $p<.46$, or both (i.e., the interaction), $F(1,111)=0.39, p<.53$.

\section{Affective States}

We computed a composite affective-states score $(\alpha=.91)$ and entered it into an ANOVA. The accountability main effect was significant. As in Experiment 3, accountable participants $(M=3.11)$ felt worse than unaccountable participants $(M=2.14)$, $F(1,111)=12.64, p<.01$. The evaluation expectancy main effect did not reach significance, $F(1,111)=0.02, p<.97$.

Interestingly, the interaction was significant, $F(1,111)=4.04$, $p<.05$. Accountable and high-evaluation-expectancy participants $(M=3.39)$ did not feel significantly worse than accountable and low-evaluation-expectancy participants $(M=2.85), F(1,111)=$ $1.63, p<.29$, although the means were descriptively in the anticipated direction (i.e., the former seemed to have somewhat stronger evaluation expectancies than the latter). However, accountable and high-evaluation-expectancy participants $(M=3.39)$ felt worse than unaccountable and high-evaluation-expectancy participants $(M=1.85), F(1,111)=15.12, p<.01$.

\section{Discussion}

In Experiment 4, we examined evaluation expectancy as a likely mechanism for why accountable and identifiable (to a high-status audience) participants curtail their self-enhancement bias. Our rationale was based on prior research showing that evaluation expectancy can lead to an internal focus on one's weaknesses, thus attenuating the positivity of self-judgments. As predicted, accountable participants who expected to be evaluated were less selfenhancing than either accountable participants who did not have evaluation expectancies or unaccountable participants who did. Thus, this experiment was successful in establishing evaluation expectancy as a reason for self-enhancement reduction among accountable and identifiable participants.

The expectation to be evaluated turned participants' attention inwards in search for their imperfections as a writer. Likewise, accountability induced in participants a focus on their inadequacies as a writer. These results are consistent with the possibility that evaluation expectancy and accountability are different mechanisms for producing a focus on one's weaknesses. Stated somewhat differently, a focus on personal weaknesses is one, but not the only, mechanism responsible for the attenuating effect of accountability on self-enhancement. Hence, the nonsignificance of the interaction on the weakness focus assessment is not problematic in light of the significance of this interaction on the main dependent measure.

\section{General Discussion}

One of the most compelling theoretical advances in social and personality psychology in the 1980s and 1990s has been the notion that individuals are particularly deft and creative self-enhancers. That is, individuals elevate (Brown \& Dutton, 1995; Sedikides \& Strube, 1997; Taylor \& Brown, 1988), maintain (Aronson, 1992; Steele, 1988; Swann, 1985), and defend (Crocker \& Major, 1989; Greenberg, Solomon, \& Pyszczynski, 1997; Tesser, 2001) their cherished self-views by using an extraordinarily inventive set of tactics and strategies.

Apparently, such tactics confer benefits to the individual in the form of subjective well-being, positive affectivity, task persistence, and successful coping with illness. At the same time, though, these tactics can be a source of personal and interpersonal setbacks. For example, task persistence can contribute to unnecessary risk taking and subsequent performance declines, whereas overconfidence can undermine careful and systematic planning. Such short-term blows may have long-term repercussions, including reduced self-esteem and subjective well-being, as well as disengagement from further effort investment in skill development. Moreover, self-enhancing tactics may backfire by disharmonizing one's psychological field (Lewin, 1951), undermining personal and social relationships, leading to others' ultimate disaffection of the self-enhancer, and contributing to his or her social isolation or even ostracism.

How to keep one's self-superiority beliefs in check is, then, a task that is worth serious empirical consideration. We reasoned that accountability has the potential to provide helpful and constructive clues. We defined accountability as the expectation of being called on to explain, justify, and defend one's appraisal of self-generated input. We were interested in situations in which accountability pressures are minimal, that is, situations in which the audience has no outcome control over the participants. We proposed that accountability can deter self-enhancement even in such presumably minimal-impact settings. Of most importance, we wanted to know what are the mechanisms through which accountability deters self-enhancement.

\section{Summary of the Findings}

We carried out four experiments. The typical experimental procedure involved participants writing an opinion essay and preparing to grade it. However, before actually assigning grades, some participants were led to believe that they were accountable to an audience, whereas others thought that they were unaccountable. Participants proceeded with grading their essay.

We were interested in relative self-enhancement. Operationally, this index reflects the difference in level of self-enhancement between accountable and unaccountable participants. We conceptualized relative self-enhancement as an index of controllability of the self-enhancement bias. This index addresses the issue of whether participants can and do control the self-enhancement bias. Specifically, relative self-enhancement pertains to how participants cope with the contradictory demands of an external situation (i.e., desire for the projection of a favorable self-image, accountability pressures) and their own private needs for a positive selfconcept. This form of self-enhancement reflects conflict between interpersonal and intrapersonal strivings. This index, however, does not allow a determination of whether shifts in reported self-evaluation are due to interpersonal versus intrapersonal concerns. 
We relied on the assumptions that accountability is a multicomponent construct (Lerner \& Tetlock, 1999, p. 255) and that such a construct can be decomposed empirically (Cronbach, 1955; Kenny \& Albright, 1987). Progressively, we located a component of accountability that was responsible for the obtained effect, and then split up experimentally this component to its likely constituents.

We obtained solid evidence that accountability deters selfenhancement. In the first experiment, we found that accountable participants gave their essays lower grades than unaccountable ones. In the second experiment, we ruled out audience concreteness and status as explanations for this effect: Accountable participants refrained from self-enhancement to a greater extent than their unaccountable counterparts even when the audience was concrete (i.e., an eponymous other) and both under conditions of high and low audience status. In the third experiment, we located identifiability as a reason for the self-enhancement reduction effect. Accountable participants tempered the evaluations of their work because they were identifiable to an audience. In the final experiment, we examined why identifiability leads to selfenhancement curtailment among accountable participants. This experiment located evaluation expectancy and a focus on one's weaknesses as explanations. Participants who are accountable and identifiable to a high-status audience and who expect to be evaluated by this audience tone down the positivity of their selfappraisals due, in part, to their focus on their incompetencies that pertain to the domain under scrutiny (i.e., writing ability). For another demonstration of this point, see Sedikides and Herbst (in press).

\section{Implications}

Recent research has led to the realization that self-enhancement is a controllable bias rather than an uneradicable cognitive illusion (Krueger, 1998; Weinstein \& Klein, 1995). Indeed, participants can and do control (i.e., diminish) self-enhancement when they evaluate themselves on modifiable (Alicke, 1985; Dunning, 1995) and ambiguous (Brown, 1986; Dunning et al., 1989) rather than unmodifiable and unambiguous traits, when they anchor their self-peer comparisons on the skill of their peers rather than their own (Kruger, 1999; Kruger \& Dunning, 1999), when they compare themselves with a concrete rather than a generalized other (Alicke et al., 1995), when they perceive having control over their future performance (Ybema \& Buunk, 1993), and when they have ample cognitive resources for processing the relevant information (Trope $\&$ Neter, 1993). Furthermore, participants can control their selfenhancement in response to social context. For example, participants show diminishment of the self-enhancement bias in response to admonitions of truthfulness and honesty (Gordon, 1987), audience status (present Experiment 2), objective external performance criteria (McKenna \& Myers, 1997), success as opposed to failure feedback (Dunning, Leuenberger, \& Sherman, 1995), and relationship closeness (Sedikides, Campbell, Reeder, \& Elliot, 2002). The present investigation complements past research by documenting the self-enhancement curtailment role of another social contextual feature: accountability.

As mentioned above, however, our investigation goes far beyond a simple illustration of the potential of accountability to deter self-enhancement. The main contribution of the investigation lies in its persistent search for mechanisms through which accountability reduces self-enhancement. In the tail end of a sequence of experiments (i.e., Experiment 4), we were able to pinpoint evaluation expectancy and the accompanying focus on one's weaknesses as mechanisms responsible for self-enhancement reduction. This finding is consistent with renewed interest in the relevance of self-focused attention for the affective, motivational, and cognitive underpinnings of the self-system (Fejfar \& Hoyle, 2000; Higgins, 1998; Sedikides \& Green, 2000b; Silvia \& Gendolla, 2001). Of importance, this finding also enriches research on accountability. Although both identifiability and evaluation expectancy have been linked with accountability (Lerner \& Tetlock, 1999), self-focus has not been given due consideration by accountability researchers.

\section{Future Research}

Two research questions emanate directly from the present findings. First, why would focus on one's inadequacies result in self-enhancement reduction? One possibility is that self-focus gives rise to perceptions of increased personal responsibility for the experimental event (i.e., having written a mediocre essay). Another possibility is that a weakness-focus leads to the realization of how tedious, long, and distant the road to personal improvement is. Either of these outcomes can lead to the induction of negative affect (e.g., sadness, low self-esteem, frustration, shame), which is known to lower self-evaluations (Sedikides, 1992b). Second, can accountability attenuate self-enhancement even in strictly private conditions? In other words, is the threat of one's public persona necessary for self-enhancement reduction? Can accountability to an imagined moral authority or to one's own self attenuate selfenhancement? More generally, we suggest that the following three classes of issues deserve further empirical attention: Contextual features, short-term and long-term changes in the self-concept, and individual differences.

\section{Contextual Features}

Structural features of the accountability situation can attenuate or accentuate self-enhancement. One such feature is audience size (Brockner, Rubin, \& Lang, 1981). Self-enhancement reduction, for example, may be a direct function of audience size.

Another feature is the extent to which the audience holds cohesive versus divided opinions of the participant's performance (Green, Visser, \& Tetlock, 2000). Consider the case in which participants are led to believe that they are accountable to two persons, one of whom is favorably and the other unfavorably predisposed toward the essay. In such a situation, accountability may be ineffective in reducing self-enhancement, as participants know that their inflated performance appraisal will receive partial backing. It would be interesting to explore in this setting the potentially interactive relation between audience favorability and audience status. For example, participants may curtail selfenhancement only when the unfavorable audience member is higher in status than the favorable one.

This investigation was concerned exclusively with preevaluation accountability. Arguably, a different self-enhancement pattern will be observed in situations of postevaluation accountability. For example, when participants are first asked to grade their essay and then to explain, justify, and defend their grades, they may commit 
themselves to a defensive tactic of justification, advocacy, and excuse for their irreversible judgment-a tactic that Tetlock et al. (1989) termed "defensive bolstering."

\section{Short-Term and Long-Term Changes in the Self-Concept}

Is accountability-induced self-enhancement reduction momentary or does it have a more lasting impact on the self-concept? Self-enhancement reduction was evoked in our research by the anticipation of a public account. Despite the inherent difficulties in separating between public and private self-presentation (Tetlock \& Manstead, 1985), self-conceptions that are formed as a function of public pressures can indeed be internalized (Tice, 1992). As such, it would be interesting to explore whether participants' essay evaluations persist for a relatively long time interval (i.e., a week or a month). It would also be informative to explore whether such changes generalize to the entire aptitude domain under consideration (i.e., self as writer).

A related issue involves participants' memory of their essay and grades. Do accountable participants remember their essay less favorably (especially after having focused on their weaknesses) than unaccountable ones? Do accountable participants remember their grades less favorably, particularly following a considerable time delay?

\section{Individual Differences}

Individual differences may moderate the accountabilityproduced reduction of the self-enhancement bias. Self-esteem is a case in point. Compared with their low self-esteem counterparts, high self-esteem individuals have a clear sense of who they are (J. D. Campbell, 1990), denigrate those who pose a threat to them or their group (Crocker \& Major, 1989), manifest the self-serving bias to an exaggerated degree (K. W. Campbell \& Sedikides, 1999), sabotage their own performance to magnify subsequent successes (Tice, 1991), and display increased egotistical behaviors when they give public accounts to a critical audience (Schlenker, Weigold, \& Hallam, 1990). It is likely, then, that high self-esteem individuals are less prone to the self-enhancement reduction effect of accountability even when the experimental situation calls for focusing on their own weaknesses. In fact, we would expect resistance and even a measure of immunity to the impact of accountability on the self-enhancement inclinations of individuals with defensive self-esteem and those who are high on narcissism. The former engage in self-presentational styles that magnify their personal strengths, in an effort to hide their weaknesses and ward off rejection (Schneider \& Turkat, 1975). Narcissists have strong beliefs of entitlement and superiority, and they are also prone to vanity and exhibitionism (Sedikides, Campbell, Reeder, Elliot, \& Gregg, 2002; Sedikides \& Gregg, 2001).

Additionally, we expect that accountability pressures will be relatively ineffective in curtailing the self-enhancement of individuals who are high on dogmatism and intolerance of ambiguity (Tetlock et al., 1989), personal need for structure (Neuberg \& Newsom, 1993), and individuation (Maslach, Santee, \& Wade, 1987), and low on uncertainty orientation (Brouwers \& Sorrentino, 1993), self-monitoring (Krosnick \& Sedikides, 1990), and shame or guilt (Tangney, Burggraf, \& Wagner, 1995). These and other individual difference variables will help delineate the boundaries of accountability influences on self-enhancement.

\section{Concluding Remarks}

The research reported in this article establishes that accountability deters self-enhancement. Of more importance, the research points to specific mechanisms through which this effect may occur. Attentional focus on one's weaknesses in a performance domain (with the focus being an outcome of evaluation expectancy under conditions of identifiability) is one (albeit not the only) process that can lead accountable participants to lower the positivity of their self-appraisals on that domain.

Research on self-enhancement has followed three distinct waves. The first wave emphasized the relevance of self-belief accuracy in adaptive functioning (Jahoda, 1958). The second wave of research highlighted overly positive self-evaluations as a marker of adaptive functioning (Taylor \& Brown, 1988). In contrast, the third wave of research has been based on the premise that both realistic and inflated self-beliefs can qualify as correlates of adaptive functioning (Aspinwall \& Taylor, 1992; Robins \& Beer, 2001; Sedikides \& Rudich, 2002). The present investigation makes the case for one social structural variable that can deflate, when necessary, self-enhancement. This variable is accountability. We hope that future research will further clarify the nuanced influences of accountability on self-enhancement. We also hope that future research will uncover additional constraints of the selfenhancement bias.

\section{References}

Alicke, M. D. (1985). Global self-evaluation as determined by the desirability and controllability of trait adjectives. Journal of Personality and Social Psychology, 49, 1621-1630.

Alicke, M. D., Klotz, M. L., Breitnenbecher, D. L., Yurak, T. J., \& Vredenburg, D. S. (1995). Personal contact, individuation, and the better-than-average effect. Journal of Personality and Social Psychology, 68, 804-825.

Aronson, E. (1992). The return of the repressed: Dissonance theory makes a comeback. Psychological Inquiry, 3, 303-311.

Aspinwall, L. G., \& Brunhart, S. M. (1996). Distinguishing optimism from denial: Optimistic beliefs predict attention to health threats. Personality and Social Psychology Bulletin, 22, 993-1003.

Aspinwall, L. G., \& Taylor, S. E. (1992). Modeling cognitive adaptation: A longitudinal investigation of the impact of individual differences and coping on college adjustment and performance. Journal of Personality and Social Psychology, 63, 989-1003.

Baumeister, R. F. (1982). A self-presentational view of social phenomena. Psychological Bulletin, 91, 3-26.

Baumeister, R. F., Heatherton, T. F., \& Tice, D. M. (1993). When ego threats lead to self-regulation failure: Negative consequences of high self-esteem. Journal of Personality and Social Psychology, 64, 141-156.

Baumeister, R. F., \& Jones, E. E. (1978). When self-presentation is constrained by the target's knowledge: Consistency and compensation. Journal of Personality and Social Psychology, 36, 608-618.

Baumeister, R. F., \& Leary, M. F. (1995). The need to belong: Desire for interpersonal attachments as a fundamental human motive. Psychological Bulletin, 117, 497-529.

Beggan, J. K. (1992). On the social nature of nonsocial perception: The mere ownership effect. Journal of Personality and Social Psychology, 62, 229-237. 
Benoit-Smullyan, E. (1944). Status, status types, and status interrelations. American Sociological Review, 9, 151-161.

Bonanno, G. A., Field, N. P., Kovacevic, A., \& Kaltman, S. (2002). Self-enhancement as a buffer against extreme adversity: Civil war in Bosnia and traumatic loss in the United States. Personality and Social Psychology Bulletin, 28, 184-196.

Brockner, J., Rubin, J. Z., \& Lang, E. (1981). Face-saving and entrapment. Journal of Experimental Social Psychology, 17, 68-79.

Brouwers, M. C., \& Sorrentino, R. M. (1993). Uncertainty orientation and protection motivation theory: The role of individual differences in health compliance. Journal of Personality and Social Psychology, 65, 102-112.

Brown, J. D. (1986). Evaluations of self and others: Self-enhancement biases in social judgments. Social Cognition, 4, 353-376.

Brown, J . D., \& Dutton, K. A. (1995). Truth and consequences: The costs and benefits of accurate self-knowledge. Personality and Social Psychology Bulletin, 21, 1288-1296.

Burger, J. M., \& Burns, L. (1988). The illusion of unique vulnerability and the use of effective contraception. Personality and Social Psychology Bulletin, 14, 264-270.

Campbell, J. D. (1990). Self-esteem and clarity of the self-concept. Journal of Personality and Social Psychology, 59, 538-549.

Campbell, K. W., \& Sedikides, C. (1999). Self-threat magnifies the selfserving bias: A meta-analytic integration. Review of General Psychology, 3, 23-43.

Chen, S., Shecter, D., \& Chaiken, S. (1996). Getting at the truth or getting along: Accuracy- versus impression-motivated heuristic and systematic processing. Journal of Personality and Social Psychology, 71, 262-275.

Cialdini, R. B., \& Trost, M. R. (1998). Social influence: Social norms, conformity, and compliance. In D. T. Gilbert, S. T. Fiske, \& G. Lindzey (Eds.), The handbook of social psychology (pp. 151-192). Boston: McGraw-Hill.

Cohen, J., Dearnley, E. J., \& Hansel, C. E. M. (1956). Risk and hazard: Influence of training on the performance of bus drivers. Operation Research Quarterly, 7, 67-128.

Colvin, C. R., Block, J., \& Funder, D. C. (1995). Overly positive selfevaluations and personality: Negative implications for mental health. Journal of Personality and Social Psychology, 68, 1151-1162.

Cottrell, N. B. (1968). Performance in the presence of other human beings: Mere presence, audience, and affiliation effects. In E. C. Simmel, R. A. Hoppe, \& G. A. Milton (Eds.), Social facilitation and imitative behavior (pp. 91-110). Boston: Allyn \& Bacon.

Crocker, J., \& Major, B. (1989). Social stigma and self-esteem: The self-protective properties of stigma. Psychological Review, 96, 608630.

Cronbach, L. J. (1955). Processes affecting scores on "understanding of others" and "assumed similarity." Psychological Bulletin, 52, 177-193.

Cvetkovich, G. (1978). Cognitive accommodation, language, and social responsibility. Social Psychology, 2, 149-155.

De Cremer, D., Snyder, M., \& Dewitte, S. (2001). "The less I trust, the less I contribute (or not)?": The effects of trust, accountability and selfmonitoring in social dilemmas. European Journal of Social Psychology, 31, 93-107.

Deutsch, M., \& Gerard, H. B. (1955). A study of normative and informational social influences upon individual judgment. Journal of Abnormal and Social Psychology, 51, 629-636.

Diener, E., Fraser, S. C., Beaman, A. L., \& Kelem, R. T. (1976). Effects of deindividuating variables on stealing by Halloween trick-or-treaters. Journal of Personality and Social Psychology, 33, 178-183.

Dobbs, M., \& Crano, W. D. (2001). Outgroup accountability in the minimal group paradigm: Implications for aversive discrimination and social identity theory. Personality and Social Psychology Bulletin, 27, 355364.

Dunning, D. (1995). Trait importance and modifiability as factors influ- encing self-assessment and self-enhancement motives. Personality and Social Psychology Bulletin, 21, 1297-1306.

Dunning, D., Leuenberger, A., \& Sherman, D. A. (1995). A new look at motivated inferences: Are self-serving theories of success a product of motivational forces? Journal of Personality and Social Psychology, 69, $58-68$.

Dunning, D., Meyerowitz, J. A., \& Holzberg, A. D. (1989). Ambiguity and self-evaluation: The role of idiosyncratic trait definitions in self-serving assessments of ability. Journal of Personality and Social Psychology, 57, 1082-1090.

Duval, S., \& Wicklund, R. A. (1972). A theory of objective self-awareness. New York: Academic Press.

Eagly, A. H., \& Chaiken, S. (1993). The psychology of attitudes. Orlando, FL: Harcourt Brace Jovanovich.

Fejfar, M. C., \& Hoyle, R. H. (2000). Effect of private self-awareness on negative affect and self-referent attribution: A quantitative review. Personality and Social Psychology Review, 4, 132-142.

Felson, R. B. (1993). The (somewhat) social self: How others affect self-appraisals. In J. Suls (Ed.), Psychological perspectives on the self (Vol. 4, pp. 1-26). Hillsdale, NJ: Erlbaum.

Geen, R. (1991). Social motivation. Annual Review of Psychology, 42, 377-399.

Gelfand, M. J., \& Realo, A. (1999). Individualism-collectivism and accountability in intergroup negotiations. Journal of Applied Psychology, 84, 721-736.

Gordon, R. A. (1987). Social desirability bias: A demonstration and technique for its replication. Teaching of Psychology, 14, 40-42.

Gordon, R. A., \& Stuecher, U. (1992). The effect of anonymity and increased accountability on the linguistic complexity of teaching evaluations. Journal of Psychology, 126, 639-649.

Green, M. C., Visser, P. S., \& Tetlock, P. E. (2000). Coping with accountability cross-pressures: Low-effort evasive tactics and high-effort quests for complex compromises. Personality and Social Psychology Bulletin, 26, 1380-1391.

Greenberg, J., \& Pyszczynski, T. (1985). Compensatory self-inflation: A public response to the threat to self-regard of public failure. Journal of Personality and Social Psychology, 49, 273-280.

Greenberg, J., Solomon, S., \& Pyszczynski, T. (1997). Terror management theory of self-esteem and cultural worldviews: Empirical assessments and cultural refinements. In M. Zanna (Ed.), Advances in experimental social psychology (Vol. 29, pp. 61-139). San Diego, CA: Academic Press.

Greenwald, A. G., \& Breckler, S. J. (1985). To whom is the self presented? In B. R. Schlenker (Ed.), The self and social life (pp. 126-145). New York: McGraw-Hill.

Harkins, S. G., \& Jackson, J. M. (1985). The role of evaluation in eliminating social loafing. Personality and Social Psychology Bulletin, 11, $457-465$.

Henchy, T., \& Glass, D. C. (1968). Evaluation apprehension and the social facilitation of dominant and subordinate responses. Journal of Personality and Social Psychology, 10, 446-454.

Higgins, E. T. (1998). Promotion and prevention: Regulatory focus as a motivational principle. In M. P. Zanna (Ed.), Advances in experimental social psychology (Vol. 30, pp. 1-46). New York: Academic Press.

Insko, C. A., Drenan, S., Solomon, M. R., Smith, R., \& Wade, T. J. (1983). Conformity as a function of the consistency of positive self-evaluation with being like and being right. Journal of Experimental Social Psychology, 19, 341-358.

Jahoda, M. (1958). Current concepts of positive mental health. New York: Basic Books.

Kenny, D. A., \& Albright, L. (1987). Accuracy in interpersonal perception: A social relations analysis. Psychological Bulletin, 102, 390-402.

Krosnick, J. A., \& Sedikides, C. (1990). Self-monitoring and self- 
protective biases in use of consensus information to predict one's own behavior. Journal of Personality and Social Psychology, 58, 718-728.

Krueger, J. (1998). Enhancement bias in descriptions of self and others. Personality and Social Psychology Bulletin, 24, 505-516.

Krueger, J., \& Clement, R. W. (1994). The truly false consensus effect: An ineradicable and egocentric bias in social perception. Journal of Personality and Social Psychology, 67, 596-610.

Kruger, J. (1999). Lake Wobegon be gone!: The "below-average effect" and the egocentric nature of comparative ability judgments. Journal of Personality and Social Psychology, 77, 221-232.

Kruger, J., \& Dunning, D. (1999). Unskilled and unaware of it: How difficulties in recognizing one's own incompetencies lead to inflated self-assessments. Journal of Personality and Social Psychology, 77, 1121-1134.

Leary, M. R., Bednarski, R., Hammon, D., \& Duncan, T. (1997). Blowhards, snobs, and narcissists: Interpersonal reactions to excessive egotism. In R. M. Kowalski (Ed.), Aversive interpersonal behaviors (pp. 111-131). New York: Plenum Press.

Lerner, J. S., \& Tetlock, P. E. (1999). Accounting for the effects of accountability. Psychological Bulletin, 125, 255-275.

Lewin, K. (1951). Problems of research in social psychology. In D. Cartwright (Ed.), Field theory in social sciences (pp. 155-169). New York: Harper \& Row.

Maslach, C., Santee, R. T., \& Wade, C. (1987). Individuation, gender role, and dissent: Personality mediators of situational forces. Journal of Personality and Social Psychology, 53, 1088-1093.

McGuire, W. J. (1985). Attitudes and attitude change. In G. Lindzey \& E. Aronson (Eds.), The handbook of social psychology (3rd ed., pp. 233346). New York: Random House.

McKenna, F. P., \& Myers, L. B. (1997). Illusory self-assessments: Can they be reduced? British Journal of Psychology, 88, 39-51.

Neuberg, S. L., \& Newsom, J. T. (1993). Personal need for structure: Individual differences in the desire for simple structure. Journal of Personality and Social Psychology, 65, 113-131.

Oettingen, G. (2000). Expectancy effects on behavior depend on selfregulatory thought. Social Cognition, 18, 101-129.

Paulhus, D. L. (1998). Interpersonal and intrapsychic adaptiveness of trait self-enhancement: A mixed blessing? Journal of Personality and Social Psychology, 74, 1197-1208.

Pemberton, M., \& Sedikides, C. (2001). When do individuals help close others improve?: Extending the self-evaluation maintenance model to future comparisons. Journal of Personality and Social Psychology, 81, 234-246.

Petty, R. E., \& Cacioppo, J. T. (1990). Involvement and persuasion: Tradition versus integration. Psychological Bulletin, 107, 367-374.

Petty, R. E., \& Wegener, D. T. (1998). Attitude change: Multiple roles for persuasion variables. In D. T. Gilbert, S. T. Fiske, \& G. Lindzey (Eds.), The handbook of social psychology (pp. 323-390). Boston: McGrawHill.

Reicher, S., \& Levine, M. (1994). Deindividuation, power relations between groups and the expression of social identity: The effects of visibility to the out-group. British Journal of Social Psychology, 33, 145-163.

Robins, R. W., \& Beer, J. S. (2001). Positive illusions about the self: Short-term benefits and long-term costs. Journal of Personality and Social Psychology, 80, 340-352.

Robins, R. W., \& John, O. P. (1997a). Effects of visual perspective and narcissism on self-perception: Is seeing believing? Psychological Science, 8, 37-42.

Robins, R. W., \& John, O. P. (1997b). The quest for self-insight: Theory and research on accuracy and bias in self-perception. In R. Hogan, J. A. Johnson, \& S. R. Briggs (Eds.), Handbook of personality (pp. 443-477). New York: Guilford Press.

Ryan, R. M., \& Connell, J. P. (1989). Perceived locus of causality and internalization: Examining reasons for acting in two domains. Journal of Personality and Social Psychology, 57, 749-761.

Sanna, L. J. (1992). Self-efficacy theory: Implications for social facilitation and social loafing. Journal of Personality and Social Psychology, 61, 774-786.

Schimel, J., Pyszczynski, T., Greenberg, J., O’Mahen, H., \& Arndt, J. (2000). Running from the shadow: Psychological distancing from others to deny characteristics people fear in themselves. Journal of Personality and Social Psychology, 78, 446-462.

Schlenker, B. R. (1980). Impression management: The self-concept, social identity, and interpersonal relations. Monterey, CA: Brooks/Cole.

Schlenker, B. R. (1997). Personal responsibility: Applications of the Triangle Model. In L. L. Cummings \& B. Staw (Eds.), Research in organizational behavior (Vol. 19, pp. 241-301). Greenwich, CT: JAI Press.

Schlenker, B. R., \& Leary, M. R. (1982). Audiences' reactions to selfenhancing, self-denigrating, and accurate self-presentations. Journal of Experimental Social Psychology, 18, 89-104.

Schlenker, B. R., \& Weigold, M. F. (1992). Interpersonal processes involving impression regulation and management. Annual Review of Psychology, 43, 133-168.

Schlenker, B. R., Weigold, M. F., \& Doherty, K. (1991). Coping with accountability: Self-identification and evaluative reckonings. In C. R. Snyder \& D. R. Forsyth (Eds.), Handbook of social and clinical psychology: The health perspective (pp. 96-115). New York: Pergamon Press.

Schlenker, B. R., Weigold, M. F., \& Hallam, J. R. (1990). Self-serving attributions in social context: Effects of self-esteem and social pressure. Journal of Personality and Social Psychology, 58, 855-863.

Schneider, D. J., \& Turkat, D. (1975). Self-presentation following success or failure: Defensive self-esteem models. Journal of Personality, 43, 127-135.

Schopler, J., Insko, C. A., Drigotas, S. M., Wieselquist, J., Pemberton, M. B., \& Cox, C. (1995). The role of identifiability in the reduction of interindividual-intergroup discontinuity. Journal of Experimental Social Psychology, 31, 553-574.

Sedikides, C. (1990). Effects of fortuitously activated constructs versus activated communication goals on person impressions. Journal of Personality and Social Psychology, 58, 397-408.

Sedikides, C. (1992a). Attentional effects on mood are moderated by chronic self-conception valence. Personality and Social Psychology Bulletin, 18, 580-584.

Sedikides, C. (1992b). Changes in the valence of the self as a function of mood. Review of Personality and Social Psychology, 14, 271-311.

Sedikides, C. (1993). Assessment, enhancement, and verification determinants of the self-evaluation process. Journal of Personality and Social Psychology, 65, 317-338.

Sedikides, C. (1997). Differential processing of ingroup and outgroup information: The role of relative group status in permeable boundary groups. European Journal of Social Psychology, 27, 121-144.

Sedikides, C., Campbell, W. K., Reeder, G., \& Elliot, A. J. (1998). The self-serving bias in relational context. Journal of Personality and Social Psychology, 74, 378-386.

Sedikides, C., Campbell, W. K., Reeder, G., \& Elliot, A. J. (2002). The self in relationships: Whether, how, and when close others put the self "in its place.” In W. Stroebe \& M. Hewstone (Eds.), European review of social psychology (Vol. 12, pp. 237-265). Chichester, England: Wiley.

Sedikides, C., Campbell, W. K., Reeder, G., Elliot, A. J., \& Gregg, A. P. (2002). Do others bring out the worst in narcissists? The "Others Exist for Me" illusion. In Y. Kashima, M. Foddy, \& M. Platow (Eds.), Self and identity: Personal, social, and symbolic (pp. 103-123). Mahwah, NJ: Erlbaum.

Sedikides, C., \& Green, J. D. (2000a). On the self-protective nature of inconsistency/negativity management: Using the person memory para- 
digm to examine self-referent memory. Journal of Personality and Social Psychology, 79, 906-922.

Sedikides, C., \& Green, J. D. (2000b). The rocky road from affect to attentional focus. In H. Bless \& J. P. Forgas (Eds.), The message within: The role of subjective experience in social cognition and behavior (pp. 203-215). Philadelphia: Psychology Press.

Sedikides, C., \& Gregg, A. P. (2001). Narcissists and feedback: Motivational surfeits and motivational deficits. Psychological Inquiry, 12, 237239.

Sedikides, C., \& Herbst, K. (in press). How does accountability reduce self-enhancement?: The role of self-focus. Revue Internationale De Psychologie Sociale.

Sedikides, C., \& Rudich, E. A. (2002). It's a matter of self-esteem: Narcissism as predictor of emotional undistress. Unpublished manuscript, University of Southampton, England.

Sedikides, C., \& Skowronski, J. J. (1991a). The law of cognitive structure activation. Psychological Inquiry, 2, 169-184.

Sedikides, C., \& Skowronski, J. J. (1991b). On the law of cognitive structure activation: Reply to commentaries. Psychological Inquiry, 2, 211-219.

Sedikides, C., \& Strube, M. J. (1997). Self-evaluation: To thine own self be good, to thine own self be sure, to thine own self be true, and to thine own self be better. In M. P. Zanna (Ed.), Advances in experimental social psychology (Vol. 29, pp. 209-269). New York: Academic Press.

Semin, G. R., \& Manstead, A. S. R (1983). The accountability of conduct: A social psychological analysis. London: Academic Press.

Sherman, S. J., Presson, C. C., \& Chassin, L. (1984). Mechanisms underlying the false consensus effect: The special role of threat to the self. Personality and Social Psychology Bulletin, 10, 127-138.

Silvia, P. J., \& Gendolla, H. E. (2001). On introspection and self-perception: Does self-focused attention enable accurate self-knowledge? Review of General Psychology, 5, 241-269.

Singer, J. E., Brush, C. E., \& Lublin, S. C. (1965). Some aspects of deindividuation: Identification and conformity. Journal of Experimental Social Psychology, 1, 356-378.

Steele, C. M. (1988). The psychology of self-affirmation: Sustaining the integrity of the self. In L. Berkowitz (Ed.), Advances in experimental social psychology (pp. 261-302). Hillsdale, NJ: Erlbaum.

Stenning, P. C. (Ed.). (1995). Accountability for criminal justice. Toronto, Canada: University of Toronto Press.

Swann, W. B. (1985). The self as architect of social reality. In B. R. Schlenker (Ed.), The self and social life (pp. 100-125). New York: McGraw-Hill.

Tangney, J. P., Burggraf, S. A., \& Wagner, P. E. (1995). Shame-proneness, guilt-proneness, and psychological symptoms. In J. P. Tangney \& K. W. Fischer (Eds.), Self-conscious emotions: The psychology of shame, guilt, embarrassment, and pride (pp. 343-367). New York: Guilford Press.

Taylor, S. E., \& Armor, D. A. (1996). Positive illusions and coping with adversity. Journal of Personality, 64, 873-898.

Taylor, S. E., \& Brown, J. D. (1988). Illusion and well-being: A social psychological perspective on mental health. Psychological Bulletin, 103, 193-210.

Tesser, A. (2001). On the plasticity of self-defense. Current Directions in Psychological Science, 10, 66-69.

Tetlock, P. E. (1983). Accountability and complexity of thought. Journal of Personality and Social Psychology, 45, 74-83.

Tetlock, P. E. (1992). The impact of accountability on judgment and choice: Toward a social contingency model. In M. P. Zanna (Ed.),
Advances in experimental social psychology (Vol. 25, pp. 331-376). New York: Academic Press.

Tetlock, P. E. (1999). Accountability theory: Mixing properties of human agents with properties of social systems. In L. L. Thompson \& J. M. Levine (Eds.), Shared cognition in organizations: The management of knowledge (pp. 117-137). Mahwah, NJ: Erlbaum.

Tetlock, P. E., \& Lerner, J. S. (1999). The social contingency model of judgment and choice: Multi-functional but still dual process? In S. Chaiken \& Y. Trope (Eds.), Dual process theories in social psychology (pp. 571-585). New York: Guilford Press.

Tetlock, P. E., \& Manstead, A. S. R. (1985). Impression management versus intrapsychic explanations in social psychology: A useful dichotomy? Psychological Review, 92, 915-934.

Tetlock, P. E., Skitka, L., \& Boettger, R. (1989). Social and cognitive strategies for coping with accountability: Conformity, complexity, and bolstering. Journal of Personality and Social Psychology, 57, 632-640.

Tice, D. M. (1991). Esteem protection or enhancement? Self-handicapping motives and attributions differ by trait self-esteem. Journal of Personality and Social Psychology, 60, 711-725.

Tice, D. M. (1992). Self-concept change and self-presentation: The looking glass self is also a magnifying glass. Journal of Personality and Social Psychology, 63, 435-451.

Tice, D. M., Butler, J. L., Muraven, M. B., \& Stillwell, A. M. (1995). When modesty prevails: Differential favorability of self-presentation to friends and strangers. Journal of Personality and Social Psychology, 69, 11201138.

Trope, Y., \& Neter, E. (1993). Reconciling competing motives in selfevaluation: The role of self-control in feedback setting. Journal of Personality and Social Psychology, 66, 646-657.

Tyler, T. (1997). The psychology of legitimacy: A relational perspective on voluntary deference to authorities. Personality and Social Psychology Review, 1, 323-345.

Weary-Bradley, G. (1978). Self-serving bias in the attribution process: A reexamination of the fact or fiction question. Journal of Personality and Social Psychology, 36, 56-71.

Weigold, M. F., \& Schlenker, B. R. (1991). Accountability and risk taking. Personality and Social Psychology Bulletin, 17, 25-29.

Weinstein, N. D. (1980). Unrealistic optimism about future life events. Journal of Personality and Social Psychology, 39, 806-820.

Weinstein, N. D., \& Klein, W. M. (1995). Resistance of personal risk perceptions to debiasing manipulation. Health Psychology, 14, 132-140.

Wicklund, R. A. (1975). Objective self-awareness. In L. Berkowitz (Ed.), Advances in experimental social psychology (Vol. 8, pp. 233-275). Orlando, FL: Academic Press.

Williams, K., Harkins, S., \& Latane, B. (1981). Identifiability as a deterrent to social loafing: Two cheering experiments. Journal of Personality and Social Psychology, 40, 303-311.

Williams, K., \& Zadro, L. (2001). Ostracism: On being ignored, excluded, and rejected. In M. Leary (Ed.), Interpersonal rejection (pp. 21-53). New York: Oxford University Press.

Wills, T. A. (1981). Downward comparison principles in social psychology. Psychological Bulletin, 90, 245-271.

Ybema, J. F., \& Buunk, B. P. (1993). Aiming at the top? Upward social comparison of abilities after failure. European Journal of Social Psychology, 23, 627-645.

Received July 9, 2001

Revision received January 23, 2002 Accepted January 28, 2002 